\title{
A Definition of Punishment for Implementing the Double Jeopardy Clause's Multiple-Punishment Prohibition
}

The double jeopardy clause of the Fifth Amendment provides that no person shall "be subject for the same offence to be twice put in jeopardy of life or limb."1 Throughout its history, the principle of double jeopardy has restricted both the government's ability to place the criminally accused on trial and its power to punish the guilty.2 In implementing the underlying policies of the double jeopardy clause, the Supreme Court has found that the clause embodies several distinct protections for criminal defendants that extend beyond its express language. ${ }^{3}$ One of those protections forbids the imposition of

1. U.S. Const. amend. V. Although every state provides for some form of double jeopardy law, either by constitutional provision, statute, or common law, see Bartkus v. Illinois, 359 U.S. 121, 154 n.9 (1959) (Black, J. dissenting); J. Sigler, Double Jeopardy 78-83 (1969), this Note examines only the federal double jeopardy provision, held applicable to the states in Benton v. Maryland, 395 U.S. 784 (1969).

2. At common law, the pleas of autrefois acquit, autrefois convict, and pardon afforded the defendant protection against double jeopardy. See United States $v$. Wilson, 420 U.S. 332, 340 (1975) (citing 3 E. CokE, Institutes 212-13 (6th ed. London 1680)). Those pleas, with some exceptions, protected the accused from a second prosecution for the same offense. See id. The common law also protected against multiple punishment for the same offense. See M. Friedland, Double Jeopardy 5, 321-35 (1969) (controversy concerning whether clerks convicted and punished in ecclesiastical courts would be exempt from further punishment in King's courts probably responsible for double jeopardy concept in common law). See also Note, Twice in Jeopardy, 75 YALE L.J. 262, 266 n.13 (1965) (preventing multiple punishment foremost in minds of framers of double jeopardy clause).

The common-law plea of autrefois convict, which prevented retrial after conviction, was rooted in a concern for preventing double punishment, not multiple trials. That plea was based on the maxim "Nemo debet bis puniri pro uno delicto," see $2 \mathrm{E}$. CokE, ReporTs pt. 4, at 43 (London 1777); Note, supra, at 265 \& n.12, which translates "No one is punished twice for the same offence." $4 \mathrm{~W}$. Blackstone, Commentaries $1710 \mathrm{n} .51$ (Lewis ed. 1902). As Blackstone explained, see $i d$. at 315 , this maxim allowed a defendant acquitted on the King's indictment to be subject to a second prosecution instituted by a private individual. Since the defendant escaped punishment in the King's court, the second trial could result in, at most, the imposition of only one punishment for the offense. Thus, during this period of history, the law valued only the ban on multiple punishment and showed no concern for barring multiple trials.

3. The separate doctrines emanating from the double jeopardy clause fall into two categories. The first category, limiting the government's ability to retry a defendant, in. cludes the following prohibitions: preventing retrial for the same offense after acquittal, United States v. Ball, 163 U.S. 662, 671 (1896); preventing retrial for the same offense after conviction, In re Nielsen, 131 U.S. 176, 186-88 (1889); according collateral estoppcl effect to issues of ultimate fact once they have been determined by a valid and final judgment, Ashe v. Swenson, 397 U.S. 436, 443, 445 (1970); recognizing a limited rule of compulsory joinder that requires joinder in a single trial of greater and lesser included offenses, Brown v. Ohio, 432 U.S. 161, $168-69$ (1977); and limiting the trial court's ability to discharge the jury before verdict, see Crist v. Bretz, 437 U.S. 28, 37-38 (1978) (jeopardy attaches when jury is empaneled and sworn; retrial not permitted where, on prosecutor's motion, court dismissed jury before first witness sworn because of error in information); Arizona v. Washington, 434 U.S. 497, 505 (1978) (defendant cannot be re- 
"multiple punishment" for a single offense. ${ }^{4}$

Although the multiple-punishment doctrine has been the subject of considerable litigation, Supreme Court decisions involving the doctrine have considered only the use of imprisonment and fines. ${ }^{5}$ The Court has recognized both those sanctions as punishment within the meaning of the double jeopardy clause. ${ }^{6}$ State and lower federal courts have been reluctant to extend the definition beyond those two traditional sanctions for purposes of the multiple-punishment prohibition. ${ }^{7}$ This Note argues that the "intent" of a challenged practice is irrelevant in defining "punishment" for double jeopardy purposes. A sanction should constitute punishment if its effects upon the offender are comparable to those of imprisonment and fines. The Note proposes a new definition of punishment for implementing the ban on multiple punishment and applies the definition to the sanction of probation, a practice frequently challenged on double jeopardy grounds.

\section{The Prohibition of Multiple Punishment}

The multiple-punishment doctrine is an integral part of the double jeopardy clause's retrial restrictions, which seek to guarantee fairness and finality in the administration of criminal justice. The multiplepunishment doctrine itself has separate components that are available to a defendant. To invoke any of the components, however, the defendant must establish that the sanction he challenges does, in fact, amount to punishment. ${ }^{\mathrm{s}}$

tried after mistrial declared over his objection unless termination of proceedings justified by "manifest necessity").

The second category of protection, commonly denoted the ban on "multiple punishment," restricts the government's ability to punish. See pp. 636-40 infra (discussing specific protections subsumed under multiple-punishment doctrine).

4. See Ex parte Lange, 85 U.S. (I8 Wall.) 163, 173 (1874) (double jeopardy clause prevents double punishment as well as retrial for same offense).

5. See, e.g., North Carolina v. Pearce, 395 U.S. 711 (1969) (imprisonment); In re Bradley, 318 U.S. 50 (1943) (imprisonment and fine); Ex parte Lange, 85 U.S. (18 Wall.) 163 (1874) (same).

6. When the incarceration is a prison sentence and is imposed after conviction, it has been universally regarded as punishment. When the confinement occurs prior to trial, see note 40 infra, or as a condition of probation, see note 45 infra, courts have not been unanimous in recognizing it as punishment.

7. Some courts, although not absolutely refusing to extend the scope of the multiplepunishment prohibition beyond the conventional sanctions of fine and postconviction imprisonment, apply an "imprisonment standard" that requires the challenged sanction to be comparable to incarceration if it is to be deemed punitive. See Hall v. Bostic, 529 F.2d 990, 992 (4th Cir. 1975), cert. denied, 425 U.S. 954 (1976) (rejecting double jeopardy claim because "person does not serve a prison sentence while on probation"); State v. Fuentes, 26 Ariz. App. 444, 454, 549 P.2d 224, 234 (1976) (Jacobsen, P.J., dissenting) (sanction must be as restrictive as incarceration to be deemed punitive for double jeopardy purposes); People v. Wilbur, 50 Ill. App. 3d 65, 68-69, 365 N.E.2d 198, 200-01 (1977) (same).

8. As used in this Note, the defendant's "sentence" is the trial court's disposition of 


\section{A. The Functions of the Double Jeopardy Clause}

The double jeopardy clause, a fundamental criminal procedural guarantee of the Constitution, ${ }^{9}$ constrains the power of both federal and state ${ }^{10}$ governments in their dealings with criminal defendants. The general function of the double jeopardy clause is to assure that the prosecution and punishment of an individual have the degrees of finality and fairness essential to administration of the criminal law. ${ }^{11}$ The principle of fairness insures that the defendant receives a punishment, set by the court and authorized by the legislature, that is commensurate with his criminal liability; ${ }^{12}$ the guarantee of finality insures that a criminal defendant, having been once convicted and punished or acquitted, not live in a state of anxiety and insecurity for fear of further prosecution or punishment ${ }^{13}$ for the same offense. ${ }^{14}$

the defendant after conviction, while the term "punishment" includes pre- and postconviction sanctions imposed by any governmental body. Further, "imposition" of sentence must be distinguished from "execution" of sentence: the former refers to the setting of sentence by the trial court, while the latter is the commencing of service of scntence by the defendant.

9. See Benton v. Maryland, 395 U.S. 784, 796 (1969) (guarantee against double jeopardy is "fundamental to the American scheme of justice") (quoting Duncan v. Louisiana, 391 U.S. 145, 149 (1968)); M. FriedLAND, supra note 2, at 3 ("[n]o other procedural doctrine is more fundamental" than rule against double jeopardy). See also J. SiGLER, supra note 1, at 2-3 (principle of double jeopardy one of oldest ideas in Western civilization, with roots in Greek, Roman, and canon law).

10. The Court held in Benton v. Maryland, 395 U.S. 784, 794-96 (1969), that the prohibition against double jeopardy is applicable to the states through the Fourteentir Amendment and that "the same constitutional standards apply against both the State and Federal Governments." Id. at 795.

11. See United States v. Scott, 437 U.S. 82, 92 (1978) (primary purpose of double jeopardy clause is to "protect the integrity of a final judgment"); Crist v. Bretz, 437 U.S. 28, 33 (1978) (one major purpose of guarantee against double jeopardy is "to preserve the finality of judgments"); United States v. Wilson, 420 U.S. 332, 343 (1975) (principles of fairness and finality underlie double jeopardy law).

12. See Neal v. State, 55 Cal. 2d 11, 20, 357 P.2d 839, 844, 9 Cal. Rptr. 607, 612 (1960) (protection against multiple punishment insures that defendant's punishment is commensurate with his criminal liability); J. SIGLER, supra note 1, at 193 (same). Equating the defendant's punishment with his criminal liability, however the latter is determined, serves the policy of faimess in the sense that similarly situated defendants will receive the same punishment. The principle of fairness is also important in the retrial context. See Arizona v. Washington, 434 U.S. 497, 503-04 (1978) (even if first trial not completed second prosecution "may be grossly unfair").

13. See Green v. United States, 355 U.S. 184, 187-88 (1957) (underlying idea of double jeopardy is to prevent government from "compelling ... [defendant] to live in a con. tinuing state of anxiety and insecurity"). This application of the finality principle is the only one relevant in the multiple-punishment area. The other applications are more appropriate to a discussion of the rationale of the retrial prohibition. See $i d$. (principlc of double jeopardy protects against embarrassment and expense of retrial and prevents enhancing possibility that innocent person will be found guilty).

14. Before a defendant may successfully invoke the protections of the double jeopardy 
The history of the double jeopardy clause indicates that the traditional scope of the ban on double jeopardy encompasses the prohibition of multiple punishment ${ }^{15}$ as well as the prohibition of retrial for a single offense. ${ }^{16}$ The multiple-punishment prohibition is a necessary corollary of the double jeopardy clause's retrial restrictions: the bar against retrying the defendant after conviction would be inadequate if, after a single trial, the court could impose any number of sentences on the defendant. ${ }^{17}$

clause, he must establish that the retrial or multiple punishment was for the "same offense." Under the Supreme Court's current test, when a single act violates two distinct statutory provisions, the act will nevertheless be treated as one offense unless each provision requires proof of a fact that the other does not. Brown v. Ohio, 432 U.S. 161, 166 (1977) (quoting Blockburger v. United States, 284 U.S. 299, 304 (1932)). See also Note, The Double Jeopardy Clause as a Bar to Reintroducing Evidence, 89 XALE L.J. 962, 965-69 (1980) (discussing various "same offense" tests).

15. See North Carolina v. Pearce, 395 U.S. 711, 717 (1969) (double jeopardy clause prevents "multiple punishments" for same offense).

Although the Supreme Court has stated that the double jeopardy clause proscribes double "jeopardy," not double "punishment," United States v. Ball, 163 U.S. 662, 669 (1896), and that the clause is written in terms of risk of trial, not punishment, Breed v. Jones, 421 U.S. 519,532 (1975), the Court has not meant to narrow or eliminate the multiple-punishment doctrine. The Court made those comments in implementing the retrial prohibition to reject the argument that only multiple punishment is barred.

16. The framers of the Bill of Rights intended the double jeopardy clause to bar both retrials and multiple punishment. The double jeopardy provision, as originally submitted by James Madison to the House of Representatives on June 8, 1789, read: "No person shall be subject, except in cases of impeachment, to more than one punishment or one trial for the same offence." I ANNals of Cong. 434 (Gales \& Seaton eds. 1789). Mr. Benson, of New York, remarked that the provision embodied the "humane intention ... to prevent more than one punishment." Id. at 753. Madison's wording survived in the House despite claims that the provision might be misconstrued to prevent a defendant from seeking a new trial after a successful challenge of his conviction. Id. But, in the Senate, the provision was rewritten to incorporate Blackstone's use of the term "jeopardy," United States v. Wilson, 420 U.S. 332, $341-42$ (1975) (citing S. JourNaL, Ist. Cong., Ist Sess. 71, 77 (1820 ed.)), and the phrase "be put twice in jeopardy of life or limb by any public prosecution" was substituted for the latter half of Madison's clause. J. StGLER, supra note 1, at 31. A conference committee later deleted the words "by any public prosecution." Id. at 31-32. The Senate modification of the double jeopardy provision attempted only to clarify the meaning of the clause by incorporating the more familiar common-law language. Id. Thus, there was no intention to eliminate the multiple-punishment prohibition. North Carolina v. Pearce, 395 U.S. 711, 729 (1969) (Douglas, J., concurring).

17. The double jeopardy clause bars retrial after conviction, not to prevent a second trial or conviction for the same offense, but to prevent the new punishment that would follow a second conviction. Ex parte Lange, 85 U.S. (18 Wall.) 163, 173 (1874). Thus, since the ban on retrial after conviction is designed to preserve the finality of the punishment imposed after the first trial, the multiple-punishment doctrine must insure that, in the absence of a second trial, the initial punishment is not increased. As the Court noted in Ex parte Lange:

[I]f, after judgment has been rendered on the conviction, and the sentence of that judgment executed on the criminal, he can be again sentenced on that conviction to another and different punishment, . . . is the constitutional restriction [against double 


\section{B. The Components of the Multiple-Punishment Doctrine}

The courts have implemented the double jeopardy clause's principles of fairness and finality in punishment by imposing three general limitations on sentencing authorities. First, the multiple-punishment doctrine requires that the sentencing court take full account of all separate punishments imposed for a single offense. ${ }^{18}$ Thus, if a criminal defendant has been reconvicted and resentenced after successfully challenging his first conviction, ${ }^{19}$ he must receive credit for the period of imprisonment served after the first trial. ${ }^{20}$ Mandating

jeopardy] of any value? Is not its intent and its spirit in such a case as much violated as if a new trial had been had, and on a second conviction a second punishment inflicted? Id.

The maxim "no one is punished twice for the same offense," which underlies the bar on retrial after conviction, see note 2. supra, is not violated when the defendant is retried after he successfully vacates his initial conviction. See Burks v. United States, 437 U.S. 1, 13-16 (1978) (defendant can be retried when conviction vacated on ground of trial error rather than insufficiency of evidence). If, after retrial and reconviction, the defendant's new sentence is not longer than the first one and if the defendant receives credit for the time served under the initial sentence, he endures only one punishment. The single punishment imposed after the first conviction is simply served over the span of two convictions.

Although the Court has held that, on reconviction, the defendant must receive credit toward a new sentence for time served under the initial conviction, see North Carolina v. Pearce, 395 U.S. 711, 717-19 (1969), it has refused to prevent the imposition of a longer sentence on retrial, see $i d$. at 719-21. This refusal thus violates the very rationale for allowing the reprosecution: the longer sentence imposed upon reconviction subjects the defendant to a second and different punishment for the same offense. $I d$. at 726 (Douglas, J., concurring); id. at 744 (Harlan, J., concurring in part and dissenting in part); cf. United States v. Difrancesco, 101 S. Ct. 426, 445-46 (1980) (Stevens, J., dissenting) (Court has never adequately responded to "powerful analysis" of Justice Harlan's Pearce opinion).

18. See North Carolina v. Pearce, 395 U.S. 711, 717-19 (1969) (crediting prison term imposed after second trial for time served after initial trial); id. at 718 (multiple-punishment doctrine violated "whenever punishment already endured is not fully subtracted from any new sentence imposed"); Culp v. Bounds, 325 F. Supp. 416,419 (W.D.N.C. 1971) (crediting prison term for time spent in pretrial confincment); Note, Credit for Time Served Between Arrest and Sentencing, 121 U. PA. L. REv. 1148, 1150-53 (1973) (arguing that failure to grant credit for pretrial confinement violates double jeopardy clause).

19. A defendant who has successfully challenged his conviction on appeal, on grounds other than insufficiency of the evidence, may be retried without violating the double jeopardy bar on retrials. Burks v. United States, 437 U.S. 1, 13-16 (1978); see note 17 supra (discussing rationale of Burks).

20. North Carolina v. Pearce, 395 U.S. 711, 717-19 (1969). Credit toward the second sentence must also include the time credited during service of the first prison term for good behavior. $I d$. at 719 n.13. The defendant must therefore receive credit for all the separate punishments endured despite the legislature's decision to deny such credit. Furthermore, the courts have an independent responsibility to determine what constitutes punishment. Cf. id. at $721 \mathrm{n.17}$ (rejecting government's argument that since initial prison term was served under invalid conviction, it did not constitute punishment) (quoting King v. United States, 98 F.2d 291, 293-94 (D.C. Cir. 1938)). 
credit for all separate punishments serves the principle of fairness by insuring that the separate punishments endured for a single offense amount to a total punishment that is commensurate with the defendant's criminal liability.

The second component of the doctrine prevents sentencing authorities from increasing the defendant's punishment after he has begun to serve his sentence. ${ }^{21}$ The trial court may not lengthen the period of punishment, increase the amount of a fine, or substitute a "more severe" type of sanction for a "less severe" one. ${ }^{22}$ This component of

21. In United States v. Benz, 282 U.S. 304, 307 (1931), the Court extended the rationale of E.x parte Lange, 85 U.S. (18 Wall.) 163 (1874), in dictum, to bar an increase in the length of a valid sentence after the defendant has begun to serve it. Thus, while Ex parte Lange concerned an additional punishment cxccuted after one complete punishment had been endurcd, the Benz dictum concerned an increase executed before the initial sentence was completely served. Although Benz made clear that the rationale of Ex parte Lange applied to prevent an increase in sentence while the initial punishment was still being served, see North Carolina v. Pearce, 395 U.S. 711, 730 (1969) (Douglas, J., concurring), the Court subsequently "confine[d] the dictum in Benz to Ex parte Lange's specific context." United States v. DiFrancesco, 101 S. Ct. 426, 438 (1980). Regardless of this narrowing of the Benz dictum, the rationale of Ex parte Lange alone prevents a trial court from increasing a punishment after the defendant has begun to serve his sentence. See 85 U.S. (18 Wall.) at 173 (after sentence executed on criminal, he cannot be again sentenced on that conviction); accord, Whalen v. United States, 445 U.S. 684, 703 (1980) (Rehnquist, J., dissenting) (double jeopardy clause as interpreted in Ex parte Lange prevents trial court from increasing sentence); M. FrIcDL.4ND, supra note 2, at 52 (interpreting $E x$ parle Lange to prevent increase in sentence after defendant "has started his punishment"); note 17 stipra (discussing rationale of Ex parle Lange).

Although the multiple-punishment doctrine prohibits an increase in the severity of punishment, it docs not prevent a reduction in severity. See United States v. Benz, 282 U.S. at 307. Thus, the defendant's interest in finality works only in his favor; an absolute interest in finality would prevent the court from both increasing and reducing the severity of punishment. See FED. R. CRIM. P. 35(b) (governing reduction of valid sentences).

22. See Reid v. Covert, 354 U.S. 1, 37 n.68 (1957) (plurality opinion) (dictum) (application of double jeopardy clause to military trials would deprive President or commanding officer of power to return case to court-martial for increase in sentence); Murphy v. Massachusetts, 177 U.S. 155, 160 (1900) (dictum) (double jeopardy protection prevents court from imposing "in invilum a second or additional sentence for the same offense, ... [and from] substitut[ing] one sentence for another").

Primarily on the authority of Ex parte Lange and the Benz dictum, federal courts of appeals have prevented two forms of sentencing abuse by trial courts. First, if the trial court imposes a valid punishment, that is, one within statutory limits, and the defendant has commenced service of that sentence, the court may not thereafter lengthen the period of punishment. See, e.g., United States v. Turner, 518 F.2d 14, 15 (7th Cir. 1975); United States v. Sacco, 367 F.2d 368, 369 (2d Cir. 1966); United States v. Adams, 362 F.2d 210, 211 (6th Cir. 1966); Kennedy v. United States, 330 F.2d 26, 27 (9th Cir. 1964). The prohibition against increased punishment also prevents the court from increasing the amount of a previously imposed fine. See United States v. Rosenstreich, 204 F.2d 321, 321-22 (2d Cir. 1953) (once defendant has begun probation, court may not increase previously imposed fine).

Second, the trial court may not substitute one type of punishment for another when this would result in a more severe disposition. The sentencing court must honor the less severe type of punishment initially imposed. See, e.g., United States v. Best, 571 F.2d 484, 486 (9th Cir. 1978) (substituting three-year probationary period for six-month prison term 
the multiple-punishment doctrine enforces the principle of finality by assuring the defendant that the court will honor its initial disposition. The ban on increased punishment, in conjunction with the time credit component, contemplates that the sentencing court, at the outset, will impose the total punishment on the offender that it deems commensurate with his criminal liability. ${ }^{23}$

The ban on increased punishment may be overcome, however, in certain limited situations in which society's interest in the administration of justice outweighs the defendant's interest in finality. Thus, the defendant's punishment may be increased if his initial sentence is invalid, ${ }^{24}$ if his initial conviction and sentence are vacated and he is reconvicted and resentenced, ${ }^{25}$ if the legislature has statutorily au-

violates ban on increased punishment); United States v. Bynoe, 562 F.2d 126, 127.29 (1st Cir. 1977) (once court has placed defendant on probation and suspended imposition of sentence, it may not thereafter substitute a $\$ 2,500$ fine for one month of probation); United States v. Teresi, 484 F.2d 894, 899 (7th Cir. 1973) (ban on increased punishment prevents court from substituting prison term for probation term); King v. United States, 98 F.2d 291, 293 (D.C. Cir. 1938) (second prison sentence more severe than first since it, unlike initial sentence, required hard labor and did not allow for "good time" credits).

23. For example, the trial court may determine that a punishment of five years is commensurate with the defendant's criminal liability and thus impose a five-year prison term. All punishments other than the prison term-for example, pretrial confinement, probation, parole-would be subtracted from the five-year term to insure that the punishment endured remains commensurate with the defendant's criminal liability. From the outset, the defendant knows the exact maximum limit of his punishment. But cf. United States v. DiFrancesco, 101 S. Ct. 426, 437 (1980) (double jeopardy clause "does not provide the defendant with the right to know at any specific moment in time what the exact limit of his punishment will turn out to be"). See note 106 infra (criticizing DiFrancesco).

24. See Bozza v. United States, 330 U.S. 160, 166-67 (1947) (sentencing court failed to impose minimum mandatory punishment required by statute); United States v. Stevens, 548 F.2d 1360, 1362 (9th Cir.), cert. denied, 430 U.S. 975 (1977) (sentencing court invalidly imposed lesser sentence than that set by plea agreement). In correcting such sentences, the court may be required to increase the length of the previously imposed punishment; the double jeopardy clause does not prevent the increase, however, because the only alternative would be to allow the guilty defendant to go completely unpunished. 330 U.S. at 166; see FED. R. CRIM. P. 35(a) (governing correction of illegal sentences).

25. North Carolina v. Pearce, 395 U.S. 711, 719-21 (1969). The defendant's intcrest in not receiving a higher sentence after retrial is outweighed by the need to give the second trial court complete freedom in both retrying and resentencing the defendant. See id. at 719-20 (power to resentence defendant upon retrial to any legislatively permitted penalty is necessary corollary of court's conceded power to retry defendant); Chaffin v. Stynchcombe, 412 U.S. 17, 25 (1973) (possibility of longer sentence recognized and accepted in Pearce as "Iegitimate concomitant of the retrial process"); Note, Twice in Jeopardy: Prosecutorial Appeals of Sentences, 63 VA. L. Rev. 325, 339-41 (1977) (Pearce and Chaffin emphasized retrial factor as justification for permitting increase in sentence). The decision in Pearce to permit an increase in sentence rests "upon the premise that the original conviction has, at the defendant's behest, been wholly nullified." 395 U.S. at 721, quoted with approval in Chaffin v. Stynchombe, 412 U.S. at 24. Thus, the Pearce exception to the ban on increased punishment should not be applicable outside the retrial context, that is, when the original conviction still stands. United States v. Durbin, 542 F.2d 486, 488 (8th Cir. 1976); see note 17 supra (criticizing Pearce exception). 
thorized the government to appeal the defendant's sentence for such an increase, ${ }^{20}$ or if other limited conditions apply. ${ }^{27}$

Finally, the multiple-punishment doctrine prohibits the sentencing court from imposing a sanction not authorized by the legislature. Thus, if the legislature provides for alternative and exclusive punishments and the defendant has completely satisfied one of those penalties, the sentencing court may not require the defendant to suffer the

26. See United States v. DiFrancesco, 101 S. Ct. 426 (1980) (upholding, against double jeopardy attack, validity of congressional statute authorizing government to appeal special dangerous offender's sentence to court of appeals for increase in length).

In DiFrancesco, the Court explicitly left open the question of whether the double jeopardy clause prevents the trial court, in the absence of statutory authority, from increasing a sentence after the defendant has begun to serve it. Id. at 435-36. Nevertheless, DiFrancesco does not affect the validity of the ban on such sentence increases by the trial court. See note 22 supra (discussing cases holding that trial court may not increase valid sentence). First, the Court's statement in DiFrancesco that sentence increases by the trial court were permitted at common law, $101 \mathrm{~S}$. Ct. at 435 , is undercut by one of the Court's authorities for the statement, Ex parte Lange, 85 U.S. (18 Wall.) 163 (1874). Although the dissent in Ex parte Lange relied upon common-law cases permitting sentence increascs, id. at 192-94, the Court, stating that there must be some limit to this power in criminal cases, $i d$. at $167-68$, held that it would be a "gross injustice" and a violation of the double jeopardy clause to allow a trial court to increase a sentence after its exccution, $i d$. at $168-73,175$. Thus, Ex parte Lange rejected the freedom accorded trial courts by the common law to increase a defendant's sentence.

Second, in the trial court cases, the judge increases the initial valid sentence without statutory authorization, the determinative factor that allowed the increase in DiFrancesco. S'e $101 \mathrm{~S}$. Ct. at 437,438 (ban on increased punishment not applicable since statute puts defendant on notice that sentence not final). Furthermore, the increase in sentence in DiFrancesco served the strong societal interest in providing for more uniform sentencing, which could be accomplished only through appellate review of sentences. See id. at 440 (purpose of challenged statute to provide consistency in sentencing). This consideration is lacking where the trial court, sua sponte, acts to increase a sentence.

Finally, a majority of the Court would affirm the ban on increased punishment as applied to trial court increases of valid sentences. The four dissenters in DiFrancesco, Justices Brennan, Marshall, White, and Sterens, would allow an increase only where the initial sentence is technically invalid, see id. at 441 n.4 (Brennan, J., dissenting), and Justice Rehnquist and Chief Justice Burger recently noted that "Ex parte Lange prevents a sentencing court from increasing a defendant's sentence... even though the second sentence is within the limits set by the legislature." Whalen v. United States, 445 U.S. 684, 703 (1980) (Rehnquist, J., dissenting).

27. Courts have approved the use of substitute punishments when the more severe sanction is imposed in response to acts committed by the defendant after sentencing. See United States v. Bynoe, 562 F.2d 126, 128, 129 (1st Cir. 1977) (defendant's actions while on probation may permit court to revoke probation and require that he serve prison term); Thomas v. United States, 327 F.2d 795, 797 (10th Cir.), cert. denied, 377 U.S. 1000 (1964) (no double jeopardy violation to revoke defendant's probation and sentence him to imprisonment).

The protections offered by the retrial prohibition are also subject to being overcome by strong societal interests. See Arizona v. Washington, 434 U.S. 497, 509 (1978) (dictum) (if jury deadlocked, defendant may be retried; defendant's valued right to have trial completed by particular tribunal outweighed by "society's interest in giving the prosecution one complete opportunity to convict those who have violated its laws"). 
alternative penalty. ${ }^{28}$ The court, in addition, may not impose sentence for more than one offense unless the legislature clearly intended to sanction the defendant's conduct as a multiple offense. ${ }^{20}$ The ban on imposing a legislatively unauthorized sanction serves the double jeopardy principle of fairness: the court can punish an offender no more harshly than the legislature intended. ${ }^{30}$

\section{The Need to Define Punishment}

Critical to any attack upon a sentence based on the multiple-punishment doctrine is, of course, an assumption that the sanction involved constitutes criminal ${ }^{31}$ punishment ${ }^{32}$ within the meaning of the double jeopardy clause. Normally, that assumption is not problematic: most sanctions challenged in multiple-punishment claims consist of fines

28. In Ex parte Lange, 85 U.S. (18 Wall.) 163 (1874), the sentencing court was authorized by statute to sentence the defendant either to imprisonment or to pay a fine, but it imposed both. After Lange had served five days of a one-year prison term and paid the fine, the court resentenced him to a new one-year sentence without fine; the court, however, did not remit the fine. On appeal, the Supreme Court held that the trial court had subjected the defendant to multiple punishment since he had already satisfied one of the alternative penalties authorized by Congress. Id. at 168-73, 175; see In re Bradley, 318 U.S. 50 (1943) (result in Ex parte Lange required even if court offers to return fine).

29. See Whalen v. United States, 445 U.S. 684 (1980) (lower court erred in sentencing petitioner for both felony murder and rape since Congress did not clearly intend that petitioner's criminal conduct be punishable as two separate offenses).

30. Although this component does not place any restrictions on the legislature's ability to divide an act into offenses, see Whalen v. United States, 445 U.S. 684, 689 (1980), it does require the legislature to indicate its intent clearly when it desires a given act to be punishable under more than one statutory provision. See Westen \& Drubel, Toward a General Theory of Double Jeopardy, 1978 Sup. Cr. Rev. 81, 116-18.

31. The sanction at issue must be implemented through the criminal process; the double jeopardy clause applies only to consequences of proceedings that are "essentially criminal," that is, consequences that include both stigma and deprivation of liberty. Breed v. Jones, 421 U.S. 519, 528-29 (1975). Proceedings are not "essentially criminal" if they result only in monetary compensation to the injured party for the amount of its loss. United States ex rel. Marcus v. Hess, 317 U.S. 537, 548-52 (1943). It should be noted that a particular type of proceeding may be deemed criminal for double jeopardy purposes, although it is not so considered under other constitutional provisions. Compare Middendorf v. Henry, 425 U.S. 25, $35-36$ (1976) (dictum) (juvenile court proceedings not "criminal prosecutions" for purposes of Sixth Amendment right to counsel) with Breed v. Jones, 421 U.S. at 530-31 (juvenile court proceedings are "criminal prosecutions" for double jeopardy purposes).

32. That a sanction is imposed through the criminal process does not necessarily mean that it is covered by the double jeopardy clause. A civil sanction may also be imposed through a proceeding that is "essentially criminal," see Helvering v. Mitchell, 303 U.S. 391, 402 n.6 (1938), but the multiple-punishment doctrine does not cover civil punishment, id. at 399 (protection against double jeopardy prohibits "attempting a second time to punish criminally"). Thus, although the retrial prohibition may apply to a particular proceeding, the multiple-punishment doctrine may not apply to some of the consequences of that proceeding. 
or imprisonment imposed after conviction. ${ }^{33}$ Difficulties arise for the reviewing court, however, when a defendant raises a multiple-punishment claim involving some other sanction.

Examination of the historical development of American double jeopardy law places the current problem of nontraditional sanctions in perspective. The terms of the clause explicitly prohibit only a second jeopardy of "life or limb." Although that language suggests that double jeopardy protections apply only to the most severe forms of punishment, ${ }^{34}$ the Supreme Court early rejected such a narrow reading of the double jeopardy clause and held that the clause covered penalties for all criminal offenses, including both misdemeanors and felonies. ${ }^{35}$ The Court's recognition of noncapital and noncorporal sanctions as punishment, despite the literal words of the double jeopardy provision, could have reflected its belief that the range of criminal punishments had increased in variety and significance since the formulation of the "life or limb" terminology. ${ }^{36}$

In the years since the Court recognized fines and imprisonment to be double jeopardy punishments, however, a variety of somewhat less restrictive, alternative sanctions, such as probation ${ }^{37}$ and parole, ${ }^{38}$ have gained importance in the American penal system. ${ }^{39}$ Imprisonment and fines have become, in comparison to the newer sanctions, the more severe modern-day penalties. As in the earlier stage of the development of double jeopardy law, the question today is again whether

33. The Court has extended the constitutional language "life or limb" to include only postconviction fines and imprisonment. See note 5 supra (citing cases).

34. See Breed v. Jones, 421 U.S. 519, 528 (1975) (literal reading of constitutional language would limit applicability of clause to most serious penalties); Commonwealth v. Simpson, $310 \mathrm{~Pa} .380,384-86,165$ A. 498, 499 (1933) (interpreting Pennsylvania double jeopardy clause, though nearly identical in wording to federal provision, to apply only to capital felonies); J. SIGLER, supra note 1, at 5 (during early common-law period "jeopardy of life and limb" referred to mutilation, especially of hands, noses, and ears, and death).

35. Ex parte Lange, 85 U.S. (18 Wall.) 163, 172-73 (1874).

36. See id. at 173 ("[A]t the time this maxim [no one can be twice placed in peril of legal penalties] came into existence almost every offence was punished with death or other punishment touching the person ....")

37. Probation provides the sentencing court with an alternative to prison. See pp. 65052 \& notes 77.79 infra (discussing probation system).

38. Unlike probation, which precedes and is intended to avoid service of a prison term, parole results in the early release from prison. While on parole, the defendant is subject to conditions restricting his freedom, the violation of which may result in the revocation of parole and reimprisonment to serve the remainder of the prison term.

39. See J. Conrad, Crime and Its Correction 273, 302 (1965) (use of prisons being replaced by use of probation); S. Rubin, The Law of Criminal Correction $251-52$ (2d ed. 1973) (probation needed to prevent overpopulation of prisons); F. WILKINSON, THE Realities of Crime and Punishment 147 (1972) (same). 
recent changes in criminal sanctions should have a corresponding impact on the construction of the double jeopardy clause.

\section{The Argument for a General Effects Test}

The state and lower federal courts have used an intent test to deny double jeopardy coverage to nontraditional sanctions within the criminal process. Analysis of the intent test demonstrates that it is designed to serve two functions not relevant to defining punishment for double jeopardy purposes. An effects test that focuses on the burden a sanction places upon its recipient would avoid the problematic nature of the intent test and would fulfill the purposes of the double jeopardy clause.

\section{A. The Intent Analysis}

Under the courts' intent test, a sanction is punitive only if it is intended to punish the offender. Such a test is not necessary in the multiple-punishment area since it does not serve the traditional functions of an intent test, to distinguish criminal from civil sanctions and to preserve certain governmental regulatory practices. Further, an intent test is inappropriate because of the difficulty of determining the purpose of criminal sanctions.

\section{The Challenge of Nontraditional Sanctions}

Defendants have sought to bring a number of newer, less restrictive sanctions-pretrial confinement, ${ }^{40}$ probation, ${ }^{41}$ and parole ${ }^{42}$-within

40. Several courts have refused to characterize pretrial confinement as punishment for double jeopardy purposes. E.g., State v. Kennedy, 106 Ariz. 190, 191-93, 472 P.2d 59, 60-62 (1970); Bennett v. State, 450 S.W.2d 652, 657 (Tex. Crim. App. 1970) (on rehearing). Some courts, however, have reached the opposite result. E.g., Parker v. Bounds, 329 F. Supp. 1400, 1401 (E.D.N.C. 1971); Culp v. Bounds, 325 F. Supp. 416, 419 (W.D.N.C. 1971); see Schornhorst, Presentence Confinement and the Constitution: The Burial of Dead Time, 23 Hastings L.J. 1041, 1065-71 (1972) (arguing that pretrial confinement constitutes punishment for double jeopardy purposes).

41. See Hall v. Bostic, 529 F.2d 990, 991 n.4 (4th Cir. 1975), cert. denied, 425 U.S. 954 (1976) (collecting cases) (probation does not constitute punishment for double jeopardy purposes).

42. Courts generally avoid the punishment issue in parole cases by simply holding that parole is "potentially a part of the original sentence," Dolan v. Swope, 138 F.2d 301, 304 (7th Cir. 1943); see United States ex rel. McGill v. Schubin, 475 F.2d 1257, 1259 (2d Cir. 1973) (per curiam), thus avoiding the multiple punishment issue. If parole is deemed punitive for double jeopardy purposes, however, the defendant who is denied credit for parole time is multiply punished even though parole is potentially a part of his initial sentence. Without credit, the defendant's prison sentence, as set by the trial court, fails to take full account of the separate punishment of parole, resulting in a punishment that is not commensurate with the offender's criminal liability. Indeed, the parolee who observes his parole conditions for a substantial period of time will receive a greater punishment than the offender who violates parole earlier in the period. 
the scope of the multiple-punishment doctrine. ${ }^{43}$ Attempts to argue that such sanctions should be deemed punishment have, however, been largely unsuccessful. In deciding the punishment issue, courts have found a practice punitive only if the legislature authorized the sanction and the trial court imposed it for the purpose of punishing. Thus, if probation is deemed to be imposed not to punish, but to rehabilitate, it is not treated as punishment for purposes of either the ban on lengthening the period of punishment ${ }^{44}$ or the time credit requirement. ${ }^{45}$

Using the intent approach, a court first examines formal legislative history to determine whether punitive or nonpunitive intent supported the legislature's authorization of a particular sanction. ${ }^{\text {t6 }}$ If the court

43. Although pretrial confinement, probation, and parole are the only sanctions heretofore challenged on double jeopardy grounds, other sanctions also deserve attention. These include: pretrial release in which the defendant must observe restrictive bail conditions; payment of a fee to a bail bondsman to make bail, which is not returned even if the defendant appears for trial; and "informal probation," in which the prosecutor suspends prosecution on the condition that the defendant serve a term similar to probation, see Model Code of Pre-Arraignment Procedure $\$ \$ 320.5 \cdot .9$ (Tent. Draft No. 5, 1972) (discussing informal probation).

44. Sce United States v. Fultz, 482 F.2d 1, 4-5 (8th Cir. 1973) (rehabilitative purpose of probation renders it nonpunitive; upon revocation of probation, court may execute a prison term not imposed when defendant commenced probation); Thomas v. United States, 327 F.2d 795, 797 (I0th Cir.), cert. denied, 377 U.S. 1000 (1964) (same); cf. notes 21 \& 22 supra (multiple-punishment doctrine prevents increase in punishment after defendant commenced service of sentence).

45. Courts have consistently held that probation does not constitute punishment for purposes of the timc credit component, see note 18 supra (prior punishment must be credited against subsequent one), since probation serves a rehabilitative purpose. E.g., Hall v. Bostic, 529 F.2d 990, $991-92$ (4th Cir. 1975), cert. denied, 425 U.S. 954 (1976); Kaplan v. Hecht, 24 F.2d 664, 665 (2d Cir. 1928).

Courts have divided on the time credit issue, however, when the conditions of probation include service of a jail term. See In re Williams, 145 Mont. 45, 56-57, 399 P.2d 732, 738-39 (1965) (service of jail term as condition of probation does not constitute punish. ment under Montana double jeopardy provision since probation imposed for rehabili. tative reasons); In re Wetzel, 150 Mont. 487, 493-95, 437 P.2d 7, 11-12 (1968) (same; citing Williams). Contra, State r. Jones, 327 So. 2d 18, 25 (Fla. 1976) (dictum) (federal double jcopardy provision requires that probationary jail term be recognized as punishment); Evans v. State, 356 So. 2d 1355, 1357 (Fla. Dist. Ct. App. 1978) (same; citing Jones).

Neverthcless, courts have recognized that probation constitutes punishment for the purpose of preventing substitution of a more severe form of punishment for a less severe one. See Unitcd States v. Bynoe, 562 F.2d 126, 128 (Ist Cir. 1977); United States v. Teresi, 181 F.2d 894, 899 (7th Cir. 1973). It is inconsistent to hold that probation constitutes punishment for purposes of the ban on substitute punishment but not for the time credit component or the ban on increased punishment.

46. That method enabled the court of appeals in Kaplan v. Hecht, 24 F.2d 664 (2d Cir. 1928), to reject a defendant's claim that his probation was punishment. In Kaplan, the first case to discuss whether probation constitutes punishment for double jeopardy purposes, the petitioner, upon revocation of probation, sought to credit his prison term for the time spent on probation. Basing his argument on the time credit component of the multiple-punishment doctrine, see p. $636 \&$ note 18 supra, Kaplan argued that he had bcen punished while on probation. $24 \mathrm{~F} .2 \mathrm{~d}$ at 665 . The court employed an intent test and rejected this contention, basing its discussion of probation on the Supreme 
can discern no express intent, it may nevertheless characterize the sanction as nonpunitive if a legitimate regulatory purpose can be assigned to it..7 A challenged sanction constitutes punishment if an expressed intent to punish can be shown, if there is no rational, nonpunitive reason for it, or if a rational, nonpunitive purpose exists but the sanction is excessive in light of that purpose.48

\section{Appropriate Uses of the Intent Analysis}

The Supreme Court's intent test applied to punishment serves two general functions. ${ }^{49}$ First, it distinguishes criminal sanctions from noncriminal sanctions. Frequently, constitutional outcomes have turned on whether a particular proceeding or sanction was considered "criminal," therefore invoking constitutional safeguards. ${ }^{50}$ It is appropriate to use an intent test to determine the threshold question: whether the particular proceeding or sanction is designed to express the community's condemnation of those who have violated its criminal law. 51

Court's decision in United States v. Murray, 275 U.S. 347 (1928), which reviewed the legislative history of the federal Probation Act. Congress had expressly authorized the use of probation, the Kaplan court found, for "reformatory, not punitive" purposes. 24 F.2d at 665 .

47. Under such analysis, the system of pretrial detention for the criminally accused has been held nonpunitive, because, in the absence of any express governmental intent, the court assumed the nonpunitive purpose of insuring the defendant's presence at trial. See Bennett v. State, 450 S.W.2d 652, 657 (Tex. Crim. App. 1970) (pretrial confinement designed to insure appearance of accused at trial).

48. See Bell v. Wolfish, 441 U.S. 520, 538-39, 560-61 (1979) (discussing intent test uscd in defining punishment for due process purposes).

49. Outside the double jeopardy context, the Court has consistently employed an intent analysis in defining punishment. In Kennedy v. Mendoza-Martinez, 372 U.S. 144 (1963), a due process case, the Court listed seven factors as indicative of punishment, one of which emphasized the effect of the sanction. See id. at 168-69. However, the Court did not rely on any of these factors; it found congressional intent sufficient to characterize as penal a statute authorizing divestiture of citizenship for draft evasion. In a more recent due process case, Bell v. Wolfish, 441 U.S. 520, 538-39 (1979), the Court declared that intent would be the sole test for determining the punishment issue under the due process clause. But see id. at 564-65 (Marshall, J., dissenting) (criticizing majority's incomplete use of Mendoza-Martinez factors). The Court has also employed an intent test in its bill of attainder and ex post facto cases, see Trop v. Dulles, 356 U.S. 86, 95-96 (1958) (plurality opinion), but, under those provisions, it has considered the severity of the challenged sanction a relevant factor in determining intent. See id. at 96 n.18; Note, Punishment: Its Meaning in Relation to Separation of Power and Substantive Constitutional Restrictions and Its Use in the Lovett, Trop, Perez, and Speiser Cases, 34 IND. L.J. 231, 250.51, 271-72 (1959).

50. See, e.g., Robinson v. California, 370 U.S. 660, 664-65, 667 (1962) (Eighth Amendment ban on cruel and unusual punishment prevents state from confining individual through criminal process for having status of drug addict; confinement through civil proceeding for such status permissible); Lloyd Sabaudo Societa Anonima Per Azioni v. Elting, 287 U.S. 329, 334-35 (1932) (assessing money penalty before administrative official rather than court does not violate due process); United States v. Zucker, 161 U.S. 475, $481-82$ (1896) (no right of confrontation in forfeiture proceeding).

51. See Hart, The Aims of the Criminal Law, 23 LAw \& Contemp. Prob. 401, 404.05 (1958) (community condemnation accompanying imposition of sanction renders sanction criminal rather than civil). 
Second, the intent test preserves regulatory practices thought by the Court to be functionally necessary to the government's operation. ${ }^{52}$ Under certain constitutional provisions, characterizing a sanction as punishment does not invoke constitutional safeguards to govern imposition of the sanction, but instead prevents the use of the sanction altogether. ${ }^{53}$ By applying an intent test, the Court permits the government to engage in practices that are intended to further particular governmental goals even though such practices would be deemed punitive and thus invalid under an effects test. Thus, an intent test permits the use of practices to preserve institutional security for pretrial detainees, ${ }^{54}$ to assure the defendant's appearance at trial, ${ }^{55}$ to set licensing standards for specified occupations, ${ }^{56}$ to effectuate deportation powers, ${ }^{57}$ and to permit imposition of public taxes. ${ }^{58}$

An intent test is unnecessary, however, in defining punishment for double jeopardy purposes because the multiple-punishment doctrine

52. See Kennedy v. Mendoza-Martinez, 372 U.S. 144, 168 (1963) (court must decide if statute is "penal or regulatory").

53. For example, the use of a sanction will be impermissible if it is deemed punitive under the ban on ex post facto laws, see Ex parte Garland, 71 U.S. (4 Wall.) 333, 377 (1866) (barring attorney from federal practice for failure to take loyalty oath held invalid), the states rights doctrine of the Tenth Amendment, see United States v. Constantine, 296 U.S. 280, 296 (1935) (invalidating federal tax as penalty imposed in addition to that specificd by state law for infraction of state criminal code), or the due process ban on punishing innocent persons, see Bell v. Wolfish, 441 U.S. 520, 535-37 (1979) (dictum) (due process clause prohibits punishing pretrial detainees).

54. In Bell v. Wolfish, 441 U.S. 520 (1979), for example, pretrial detainees confined in a federal correctional facility challenged the use of allegedly dehumanizing practices that the government contended were necessary to preserve institutional security. The Court rejected the claim that subjecting pretrial detainees to such practices violated the due process clause. Applying an intent test, see p. 644 supra (discussing Court's intent test), the Court found that the challenged practices before it-double-bunking, restrictions on incoming mail, room searches, and body-cavity checks-did not amount to punishment. There was no expressed intent to punish on the part of the prison officials, and a legitimate, regulatory purpose-institutional security-justified the challenged practices.

55. The due process principle at issue in Bell $v$. Wolfish concerned the government's ability to "punish" pretrial detainees, who are, of course, innocent until and unless convicted at trial. The Court explicitly recognized in Wolfish that the due process clause prohibits the punishing of pretrial detainees. See 441 U.S. at 535-37. Had the Court adopted an effects test in Wolfish, it would have invited an end to pretrial detention itself since the serere effects of such confinement upon detainees would render it punitive.

56. See Hawker v. New York, 170 U.S. 189, 200 (1898) (barring physician from practice of medicine because of criminal conviction held not punishment under ban on ex post facto laws since it serves regulatory purpose of setting job standards).

57. Mahler v. Eby, 264 U.S. 32, 39 (1924) (upholding deportation of aliens convicted of espionage on ground that deportation did not constitute criminal punishment under ban on ex post facto laws).

58. An effects test would render tax schemes punitive since they burden the taxpayer in a manner analogous to fines. To preserve the legislature's general taxing power, an intent test is employed: if the tax is imposed to raise funds it will be upheld, but if it is imposed to penalize it will be invalidated. See Lipke v. Lederer, 259 U.S. 557, $561-62$ (1922) (tax scheme invalidated because designed to suppress crime instead of raise revenue to support government). 
does not involve either of the two functions furthered by the Court's intent test. The application of the multiple-punishment doctrine to a given sanction does not threaten the government's use of that sanction. It only limits the number of sanctions that may be meted out. ${ }^{59}$ The other function of an intent test, distinguishing criminal from civil sanctions, is not relevant in cases involving concededly criminal penalties. The question thus becomes whether the internal logic of the intent approach should impel the Court to adopt it in administering the multiple-punishment doctrine.

\section{The Problematic Nature of Intent in Punishment}

As a means of defining punishment for purposes of administering the multiple-punishment doctrine, the courts' intent analysis is analytically deficient. Legislative intent is difficult to determine in any context. $^{60}$ The problem of discerning legislative purpose is particularly difficult in the criminal-law context. A court applying an intent test must first identify the primary purpose or set of purposes underlying the challenged sanction. The legislature rarely indicates its goals in authorizing the use of a particular criminal sanction. The court can then turn to penological literature, which suggests that criminal penalties serve a variety of public purposes: retribution or "vengeance," 61 deterrence of criminal conduct, ${ }^{62}$ incapacitation of the offender, ${ }^{63}$ and rehabilitation. ${ }^{64}$ Once the court articulates the purpose

59. Cf. Washington v. Davis, 426 U.S. 229, 248 (1976) (Court refuses to adopt effects test in discrimination cases brought under equal protection clause because it would "be far-reaching and would raise serious questions about, and perhaps invalidate, a whole range of tax, welfare, public service, regulatory, and licensing statutes"); Railway Express Agency, Inc. v. New York, 336 U.S. 106, 112-13 (I949) (Jackson, J., concurring) (Court should examine challenged ordinances under equal protection clause rather than due process clause since former does not disable government from dealing with subject at hand, while latter frequently does).

60. First, there may be no single purpose for a particular enactment. See United States v. O'Brien, 391 U.S. 367,384 (1968) (different legislators may have different reasons for supporting same legislation); Ely, Legislative and Administrative Motivation in Constitutional Law, 79 YALE L.J. 1205, 1213-14 (1970) (legislator may have more than one purpose in enacting particular statute). Second, it is often difficult to infer intent from available legislative materials. Committee reports and floor debates reveal the intentions of only those legislators who took public stands on the legislation. Moreover, at the state level, such materials frequently do not exist. See Clark, Civil and Criminal Penalties and Forfeitures: A Framework for Constitutional Analysis, 60 Mins. L. Rev. 379, 443 (1976).

61. See Hawkins, Punishment and Moral Responsibility, 7 MOD. L. REv. 205, 205-08 (1944) (retribution is primary ground of punishment); Mabbott, Punishment, 48 Mind 152 (1939) (punishment is imposed solely for retributive purposes).

62. See Andenaes, The General Preventive Effects of Punishment, 114 U. PA. L. Rev. 949 (1966) (criminal punishment serves purpose of deterrence).

63. See H. Packer, The Limits of the Criminal Sanction 48 (1968) (incapacitation is simplest justification of punishment involving physical restraint).

64. See id. at 53 (rehabilitation is most appealing justification of punishment); $\mathrm{E}$. 
of a sanction, it must then decide whether that purpose is punitive. Courts and commentators are divided on whether particular goals, for example, rehabilitation, should be deemed punitive. ${ }^{65}$

The court's task becomes even more difficult because the original intention of the legislature is often transmuted in practice: a sanction arguably intended by legislators as nonpunitive becomes essentially punitive through implementation by latw-enforcement officials and the courts. The rehabilitative goals of the juvenile court system, for example, although nonpunitive in their inception, have not altered the punitive nature of the treatment of juvenile offenders. ${ }^{66}$ More generally, many commentators have noted that the rehabilitative ideal may actually have increased the cruelty of the criminal justice system. ${ }^{67}$

The transformation of legislative intent is especially relevant in the probation area. Although the original federal Probation Act may have had a rehabilitative purpose, amendments have successively increased the severity of the permissible conditions. ${ }^{68}$ Moreover, there are often several "intending" actors responsible for the offender's probationary conditions, any one of whom may alter the legislature's rehabilitative goals. For example, the sentencing judge or probation officer may impose certain conditions for punitive reasons. Similarly, a proba-

Wright, The Politics of Punishment 42-49, 154 (1973) (criminal sanctions serve to rehabilitate); Allen, Criminal Justice, Legal Values and the Rehabilitative Ideal, $50 \mathrm{~J}$. CRIM. L.C. \& P.S. 226, 226-27 (1959) (discussing development of rehabilitative approach to corrections).

65. Compare Brisco v. United States, 246 F. Supp. 818, 819 (D. Del. 1965), aff'd, 368 F.2d 214 (3d Cir. 1966) (Youth Corrections Act constitutional because it serves rehabilitative, not punitive, purpose) and E. WRIGHr, supra note 64, at 42-49, 154 (incarceration serves rehabilitative, or treatment, purpose, not punitive goal) with United States v. Brown, 381 U.S. 437, 458 (1965) (rehabilitation is one purpose of punishment) and $\mathrm{H}$. ABADINSKY, Probation and Parole 9-12 (1977) (same).

66. The Supreme Court has recognized that the original idealistic notions of a flexible, treatment-ariented juvenile court system have not been realized and that juveniles therefore need procedural protections, such as the right to counsel, In re Gault, 387 U.S. 1 (1967), the protection of the reasonable-doubt standard, In re Winship; 397 U.S. 358 (1970), and the bar against double jeopardy, Breed v. Jones, 421 U.S. 519 (1975).

67. See A. von Hirsch, Doing Justice at xxxviii (1976) (rehabilitative model is more cruel than "frankly punitive" model); S. RubIN, supra note 39, at 160-66 (rehabilitative model led to longer periods of incarceration than punitive system); E. WRight, supra note 64 , at 50-51 (rehabilitative theory has not altered custodial nature of prisons); Allen, sutra note 64 , at 229 (rehabilitative ideal led to increased severity of penal measures).

68. In 1970, Congress authorized the sentencing court to require the offender to reside in a residential community treatment center. Act of Oct. 22, 1970, Pub. L. No. 91-492, $\$ 1,84$ Stat. 1090 (codified at 18 U.S.C. $\$ 3651$ (1976)). In 1972, Congress amended the Probation Act to permit the court to require that the probationer participate in a community supervision program. Act of May 11, 1972, Pub. L. No. 92-293, $\$ 1$, 86 Stat. 136 (codified at 18 U.S.C. $\$ 3651$ (1976)). See Criminal Code Reform Act of 1977, S. 1437, 95th Cong., 2d Sess. $\$ 2103(b)$ (1978) (proposing amendments to Probation Act; providing for 18 permissible probation conditions). 
tioner who is placed in a residential community treatment center will be subject to numerous institutional rules established by the particular treatment center.

\section{B. The Alternative Approach: An Effects Test}

In making the presence of punitive intent the benchmark for punishment, the courts in multiple-punishment cases have avoided the need for further analysis of defendants' claims that sentencing authorities have violated the underlying principles of the double jeopardy clause. In particular, they have eschewed inquiry into both the actual effects of the challenged sanctions upon the offender and the significance of those effects in applying the components of the multiplepunishment doctrine. ${ }^{69}$ In the administration of the double jeopardy clause, the alternative to an intent analysis is an assessment of the effect of a challenged sanction upon the individual in the criminal process. An effects test would have the virtue of avoiding uncertain searches for purposes of particular sanctions and the need to classify those purposes as punitive or nonpunitive.

The case for an effects test, however, is not rendered compelling simply by the inadequacies of the intent analysis. The double jeopardy clause's guarantees of fairness and finality in the retrial context cannot be understood except by reference to the effect of a challenged government action upon the criminally accused. In implementing the retrial prohibition, the Court has consistently based its decisions on the effects that a second trial would have upon the accused. ${ }^{70}$ The Court has noted that retrying the defendant subjects him to embarrassment, expense, and ordeal; ;1 compels him to live in "a continuing state of anxiety and insecurity"; ${ }^{72}$ and prolongs the period during

69. The district court in Hall v. Bostic, 391 F. Supp. 1297 (W.D.N.C. 1974), the only federal court to require time credit for probation on double jeopardy grounds, examined the specific conditions placed on the probationer and remarked that "[a]nybody who complies with all those conditions must be an exceptional individual." Id. at 1300. On appeal, the Fourth Circuit reversed, 529 F.2d 990 (4th Cir. 1975), cert. denied, 425 U.S. 954 (1976), on the ground that, despite the restrictive nature of the sanction, probation was reformatory and not comparable to incarceration. A discussion of the specific conditions of probation was therefore unnecessary. The Supreme Court subsequently denied certiorari, as it has done in similar cases. E.g., Thomas v. United States, 327 F.2d 795 (10th Cir.), cert. denied, 377 U.S. 1000 (1964); Allen v. United States, 209 F.2d 353 (6th Cir. 1953), cert. denied, 347 U.S. 970 (1954).

70. See Breed v. Jones, 421 U.S. 519,530 (1975) (juvenile proceedings impose "heavy pressures and burdens-psychological, physical, and financial-on a person charged").

71. See Green v. United States, 355 U.S. 184, 187 (1957).

72. Id. 
which he will be stigmatized. ${ }^{73}$ In the retrial context, the Court has rejected the argument that a rehabilitative purpose renders a proceeding nonpunitive. ${ }^{4}$

The same policy considerations, fairness and finality, underlie both the ban on multiple punishment and the retrial prohibition. ${ }^{75}$ Prohibiting exposure to multiple trials would be insufficient if the government could later impose multiple sanctions. Moreover, if mere exposure to a sanction more than once is impermissible, then a lack of finality in imposing the sanction itself should a fortiori be unacceptable. Use of an effects test in defining punishment would insure that courts continue to analyze double jeopardy issues in terms of the effects of the criminal process upon the defendant.

\section{Determining Punishment Under an Effects Test}

The Supreme Court has identified two distinguishing characteristics of criminal punishment: stigma and deprivation of liberty or property. ${ }^{76}$ In the double jeopardy context, the Court has recognized that postconviction fines and imprisonment constitute punishment. Both of those sanctions impose deprivations upon the defendant and identify him as a person worthy of community condemnation for violating the criminal law. Thus, an effects test would identify as punishment any sanction that imposes both criminal stigma and deprivations upon the offender. Under this test, a number of other sanctions would be considered punishment.

Probation, for example, stigmatizes the offender, giving him criminal status, and subjects him to deprivations and to the control of the government. Conditions of probation range from a simple require-

73. See Arizona v. Washington, 434 U.S. 497, 504 (1978). The Court has also noted that the letrial prohibition is grounded on the "minimization of harassing exposure to the harrowing experience of a criminal trial." Crist v. Bretz, 437 U.S. 28, 38 (1978); see M. FrIEDLAND, supra note 2, at 3-4 (retrial restrictions are concerned with effects of trial upon accused); Note, Statutory Implementation of Double Jeopardy Clauses: New Life for a Moribund Constitutional Guarantee, 65 YALE L.J. 339, 340-41 (1956) (same).

74. Breed v. Jones, 421 U.S. 519, 530 n.12 (1975) (juvenile court proceedings fall within double jeopardy clause's ban on retrials, even though jurenile commitments are intended to rehabilitate not punish).

75. See United States v. Wilson, 420 U.S. 332, 343 (1975) (interests underlying retrial prohibition and ban on multiple punishment are "quite similar").

76. See Breed v: Jones, 421 U.S. 519,529 (1975) (proceeding is essentially criminal if possible consequences include stigma and loss of liberty for several years); In re Winship, 397 U.S. 358, 363-61 (1970) (criminal prosecution subjects defendant to stigma and possible loss of liberty); North Carolina v. Pearce, 395 U.S. 711, 718 \& n.12 (1969) (recognizing imprisonment and fines as criminal punishment for double jeopardy purposes). 
ment that the probationer not violate the laws of the jurisdiction to more onerous deprivations. The court may restrict a probationer's movements and behavior, ${ }^{77}$ require restitution to the victim, ${ }^{78}$ and require regular reports to a probation officer..$^{79}$ Because probation has the effect of stigmatizing the offender and subjecting him to government control, it should be deemed punishment for double jeopardy purposes. ${ }^{80}$

The effects test would also extend double jeopardy protection to preconviction sanctions. The double jeopardy clause is not concerned only with the resolution of a trial and with the postconviction consequences of the criminal process; the retrial prohibition also protects the accused from another trial even though he has not endured a complete trial and judgment. ${ }^{81}$ Similarly, the multiple-punishment doctrine should cover all punitive sanctions imposed for a single offense, regardless of whether they are endured before or after conviction. For purposes of the multiple-punishment doctrine, preconviction sanctions that have effects essentially identical to those of postconviction punishments should be considered punishment.

Thus, for example, pretrial confinement would be deemed punishment for double jeopardy purposes because its punitive effect on the detainee, primarily the deprivation of liberty, is nearly identical to that of postconviction incarceration. Similarly, preconviction informal

77. Conditions of probation include requirements that the offender permit otherwise unlawful warrantless searches of his home or wórkplace, see Annot., 79 A.L.R. 3d 1083 (1977) (collecting cases challenging this requirement), avoid particular types of employment, see Annot., 35 A.L.R. Fed. 631 (1977) (collecting cases challenging this requirement), not leave the jurisdiction or marry without permission, see D. Dressler, Practice and Theory of Probation ANo Parole 188-89, 195-96 (1959), and aroid disreputable places and associates, see id. at 192-93. See also $\mathrm{H}$. ABadinsky, stupra note 65, at 123-25 (sample probation agreement).

In the federal system, judges are authorized by statute to impose stch conditions as they deem best. Probation Act, 18 U.S.C. $\$ 3651$ (1976). The federal probation statutc also lists several permissible conditions, including pasing a fine, providing for the support of those for whom the offender is legally responsible, and residing in a residential community treatment center. $I d$.

78. 18 U.S.C. $\$ 3651$ (1976) (judge may require that probationer make restitution to injured party); D. DRESSLLR, supra note 77, at 176-77 (discussing restitution as condition of probation).

79. See D. DRESSLER, supra note 77 , at $179-83$ (discussing reporting requirement).

80. Under this test, parole would also be deemed punitive, and, thus, the time credit component would require, if parole is revoked, that the parole time be credited towand the service of the remainder of the prison term. See Conner v. Griffith, 238 S.E.2d 529 (W. Va. 1977) (requiring time credit for parole under West Virginia double jeopardy provision).

81. See note 3 supra (double jeopardy clause restricts court's ability to discharge jury prior to verdict). 
probation $^{82}$ and time spent on bail under restrictive conditions ${ }^{83}$ would be deemed punitive because they replicate the effects of postconviction probation. On the other hand, a defendant's appearance before a grand jury would not constitute punishment; it does not replicate in kind or degree any of the recognized postconviction punishments.

\section{Applying the Effects Test to Probation}

The requirements of an effects test may be illustrated by applying it to the sanction of probation. Upon finding that the burdens of probation constitute punishment, ${ }^{84}$ the court would determine whether the conditions of probation imposed on the defendant amounted to multiple punishment. The analysis would examine the sanction in light of the full credit and finality components of the multiplepunishment doctrine.

\section{A. The Current Structure of Probation}

Within the federal system, a court that places an offender on probation is empowered either to impose a suspended sentence of imprisonment or fine or to decline to impose $a b$ initio a sentence of fine or imprisonment. ${ }^{85}$ If the court imposes a suspended sentence, then the offender is aware of the maximum prison term or fine he faces, and, if it is necessary to revoke probation, the court must execute the sentence originally imposed or a lesser sentence. ${ }^{86}$ If, on the other hand, no sentence is imposed, the offender is not aware of the sentence he will ultimately receive, and, if probation is revoked, the court may impose and execute any sentence that the statutes authorized $a b$ initio. ${ }^{87}$

Whatever its original disposition respecting the sentence, the court sets the length of the probationary period ${ }^{88}$ and stipulates any conditions that the defendant must observe. ${ }^{89}$ In some jurisdictions, a probationer required to serve a prison sentence following violation of probation may receive credit toward his sentence for time spent in

82. "Informal probation" allows the prosecutor to suspend prosecution on the condition that the defendant serve a term similar to probation. See MODEL Code of PrE.IRruignment Procedure, supra note 43, $\$ \$ 320.5 \cdot .9$ (discussing informal probation).

83. See 18 U.S.C. $\$ 3146$ (1976) (listing permissible bail restrictions).

84. See pp. 649-51 supra (discussing effects test in multiple-punishment area).

85. 18 U.S.C. $\$ 3651(1976)$.

86. See id. $\$ 3653$.

87. See id.

88. In the federal system, the probationary period may not exceed five years. See id. $\$ 3651$.

89. See pp. 649.50 \& notes 77-79 supra (discussing probation conditions). 
compliance with the terms of probation. The majority of states and the federal system, however, deny such credit.90

\section{B. Full Credit and Finality in Probationary Sanctions}

If the probationary conditions constitute criminal $^{91}$ punishment $^{92}$ within the meaning of the double jeopardy clause, ${ }^{93}$ the question remains whether, given the manner in which probation has been imposed in a particular case, the government has subjected the offender to multiple punishment. If the probationer completes a punitive term of probation successfully, he is released from the custody of the authorities; in such a case, there is no multiplicity of effects. If, however, the probation is revoked, the probationer may be subjected to fine or imprisonment, or both.

\section{Determining Full Credit}

When the probationer is subsequently sent to prison for violation of the conditions of probation, the sentencing authority ${ }^{94}$ must take full account of the time served on the probationary term, or the of-

90. Among the states and the District of Columbia, six jurisdictions credit an inmate's sentence for time spent on probation, five vest the trial court or attorney general with discretion to grant credit, two grant credit only if the violation does not constitute a separate criminal offense, and the remainder deny credit. See R. HAND \& R. SINGER, Sentencing Computation Laws and Practice (1974) (appendix chart). In the federal system, credit is granted only if the probationer was confined in a "jail-type facility" as a condition of probation and only for the days spent in the facility. See U.S. Bureau of Prisons, Program Statement $\$ 5 . b(4)$ (Sept. 5, 1979) (No. 5880.24).

91. Given that a particular proceeding is criminal, sanctions flowing from that proceeding should be recognized as criminal sanctions unless they directly compensate an identifiable injured party. See United States ex rel. Marcus v. Hess, 317 U.S. 537, 548-52 (1943) (court proceeding is not criminal for double jeopardy purposes if it results in compensation to injured party). Thus, if the court required that the offender make restitution to the victim of his offense, the restitution payments would not fall within the multiple-punishment doctrine since they are not criminal sanctions.

92. When the conditions of probation impose only a burden placed on the general public, the probation should not be deemed punitive. To constitute punishment, the probationary conditions must impose restrictions that would not exist but for the con. viction. Thus, if the sole condition requires either that the offender not violate the general criminal law or that he support his dependents, the probation would not be considered punishment since those obligations apply to everyone.

93. It is also necessary that the multiple punishment be imposed for the "same offense" if the double jeopardy clause is to apply. As the courts have noted, if the defendant's probation is revoked and he is imprisoned, the prison term is imposed as punishment for committing the original criminal violation, not for violating the condition of probation. See Pollard v. United States, 352 U.S. 354, 357 (1957); Hall v. Bostic, 529 F.2d 990, 992 (4th Cir. 1975), cert. denied, 425 U.S. 954 (1976).

94. Probation time may be credited through two methods: either the sentencing court will grant credit when executing the prison term, see Mo. ANN. STaT. $\$ \$ 559.026(3)$, $.036(3)$ (Vernon 1979), or an administrative structure within the prison system will grant such credit. See 18 U.S.C. $\$ 3568$ (1976) (Attorney General to credit federal prisoner's sentence for preimprisonment time). 
fender would be punished twice: he, in effect, would be required to serve the probation time again in prison.

The court must decide how to give full credit for the probation time. ${ }^{95}$ Although the conditions of probation may render it punitive, they may not be sufficiently restrictive to equate one day of probation to one day of imprisonment for time credit purposes. Yet, because a court, looking only to the double jeopardy clause, is not competent to derive a formula for granting partial credit, courts should grant maximum credit, day for day, absent a different legislative policy ${ }^{913}$ Thus, any day during which the probationer was deprived of liberty because of the probation restrictions would be equated to a day of imprisonment. ${ }^{97}$ If the legislature has provided the relevant conversion formulas, partial probation credit could be awarded without violating the multiple-punishment doctrine, since that doctrine recognizes that the severity of a punishment is a factor to be considered in preventing multiple punishment. ${ }^{98}$ Any such legislative standards would, however, have to establish reasonable conversion formulas to insure that the offender's total punishment remains commensurate with his criminal liability. ${ }^{90}$

95. In North Carolina v. Pearce, 395 U.S. 711, 718-19 (1969), the Court stated that initial punishment must be "fully "credited" against a subsequent sentence. Thus, a sentencing procedure would be impermissible if it authorized the judge to announce at the outset the exact amount of time to be served if probation is revoked. Since the amount of time spent on probation depends upon when the probationer violates his conditions and upon when he is taken into custody, this type of sentencing scheme does not take full account of the prior punishment.

96. The multiple-punishment doctrine requires resolving doubts in favor of the offender. See Westen \& Drubel, supra note 30, at 109-11. That the court should grant the maximum possible credit in the absence of legislative direction does not mean that the legislature cannot resolve those doubts against the defendant in a reasonable manner. See note 99 infra (discussing reasonableness requirement); cf. Carlson v. Green, $100 \mathrm{~S}$. Ct. 1468, 1472 (1980) (victim of constitutional violation committed by federal officer has right to damages recovery despite lack of statute conferring such right; Congress may extinguish right to damages by explicitly providing substitute and equally effective remedy). Thus, the legislature could provide that probation time would be credited on a partial basis if conditions less restrictive than imprisonment were imposed, for example, limiting travel to the county of residence.

97. The "voluntariness doctrine" of United States v. Scott, 437 U.S. 82, 99 (1978) ("Double Jeopardy Clause... does not relieve a defendant from the consequences of his voluntary choice"), could arguably be applied to deny the defendant time credit for probation either because he initially chose probation instead of a prison term or because he voluntarily violated the conditions of probation. Scott, however, dealt with the retrial prohibition, not the multiple-punishment doctrine. The Supreme Court decision in North Carolina v. Pearce, 395 U.S. 711, 717-19, 721 \& n.17 (1969), rejected the application of the "voluntariness doctrine" to the time credit area. There, the defendant voluntarily had his conviction set aside, yet he received credit toward his second prison term for time served under the first, invalid conviction.

98. See note 22 supra (ban on substitute punishment requires that court compare different types of sanctions for differences in severity).

99. The conversion formulas established by the legislature must satisfy a standard of reasonableness; without such a requirement, the legislature could circumvent the 
The multiple-punishment doctrine also requires that the court grant the offender full credit for any fines imposed. ${ }^{100}$ This requirement is easily satisfied when the court credits a fine imposed as a condition of probation against a fine executed upon revocation of probation. However, if the court requires a fine as a condition of probation and executes a prison term, but no fine, at the time of revocation, it is faced with crediting a punishment represented in units of money against one represented in units of time. ${ }^{101}$ In the absence of a reasonable legislative solution, ${ }^{102}$ the court itself must adopt a conversion equation if the offender is to receive the protection of the multiple-punishment doctrine. ${ }^{103}$

\section{Assuring Finality}

The multiple-punishment doctrine also prohibits lengthening or increasing the severity of a punishment once it has been executed by

double jeopardy principles of fairness and finality. The courts should apply these principles independently of legislative opinion to determine what constitutes punishment for double jeopardy purposes. Once a court has deemed a sanction punitive, the legislature should not be allowed to nullify that determination by establishing conversion formulas that accord the initial punishment unreasonably low credit value. As the burden of the initial sanction approaches the severity of the subsequent sanction, the credit formula must move closer to the day-for-day requirement. Thus, it would be unreasonable to credit a subsequent prison term on less than a day-for-day basis for probation time spent in a residential community treatment center. See A. von HIRsch, supra note 67 , at 108.09 (discussing incarcerative nature of community-based centers).

100. North Carolina v. Pearce, 395 U.S. 711,718 n.12 (1969).

101. In discussing time credit in North Carolina v. Pearce, 395 U.S. at 718 \& n.12, the Supreme Court did not address the issue of converting monetary sanctions into time sanctions, noting only that days should be credited against days and fines against fines. See United States v. Barash, 428 F.2d 328, 331-32 (2d Cir. 1970) (discussing difficulty of comparing fines with imprisonment for purpose of determining if defendant's punishment, upon retrial, had been increased).

102. As in the case of crediting nonmonetary sanctions against one another, see note 99 supra, the conversion equations for fines would have to be reasonable. Cf. CAL. Penal Code $\$ 2900.5(a)$ (West Supp. 1980) (statutory system requires crediting days in presentence custody against fines imposed after conviction, with one day in custody having conversion value of at least $\$ 30$; court may, in its discretion, increase monetary value of day in presentence custody).

103. Thus, for example, the court could use the federal minimum wage to convert fines to days and vice versa. This conversion formula need not be used, howercr, if the court imposed no fine as a condition of probation and, upon revocation, it executes only a fine; in that situation, the court could require payment of the proportion of the fine that corresponds to the proportion of the probation period remaining at the time of revocation. If the offender had forty percent of his probation term remaining, he would pay forty percent of the fine.

To the extent possible, a sanction should be credited only against a sanction measured in the same units. For example, if the court is crediting six months of pretrial confinement against both a five-month jail term and a $\$ 500$ fine, it should first credit the six months against the jail term and then credit the remaining month of pretrial time against the fine. Since time-to-money crediting is less accurate than crediting in kind, it should be aroided if possible to insure that the total punishment remains commensurate with the defendant's criminal liability. 
the trial court. ${ }^{104}$ The protection against increased punishment would place two restrictions on the court with respect to punitive probation. First, the court would have to establish, at the time the defendant is placed on probation, the total punishment to which he may be subjected.105 Thus, upon revocation of probation, the court could not lengthen the period of punishment. ${ }^{106}$ Second, the court could

104. See Ex parte Lange, 85 U.S. (18 Wall.) 163, 173 (1874) (punishment cannot be increased after it has been executed on defendant); pp. 637-38 \& note 22 supra; cf. United States v. Dilorenzo, 429 F.2d 216, 221 (2d Cir. 1970), cert. denied, 402 U.S. 950 (1971) (permitting increase in sentence when defendant had not yet commenced service of that sentence).

105. Requiring the trial court to impose a total punishment at the outset raises questions about the validity of the current procedures used in placing a defendant on probation. The court may either impose a prison term, fine, or both, suspend execution, and place the defendant on probation, or place the defendant on probation without imposing any term of imprisonment or fine. See 18 U.S.C. $\$ 3651$ (1976). If the court selects the second method and imposes punitive conditions, it can only require, upon resacation, that the defendant either serve the remainder of his probationary term in prison or pay a fine proportionate to the time that remained in the probation period. Since the probation term and the subsequent prison term or fine are imposed for the same initial criminal conduct, see note 93 supra, there is no reason why the court cannot, at the outset, determine what length of punishment is commensurate with the defendant's liability. Further, cases holding that the trial court can delay imposition of a prison term until probation is revoked, see United States v. Fultz, 482 F.2d I, 4-5 (8th Cir. 1973); Thomas v. United States, 327 F.2d 795, 797 (10th Cir.), cert. denied, 377 U.S. 1000 (1964); cf. United States v. DiFrancesco, 101 S. Ct. 426, 437 (1980) (approving Thomas), have sustained this procedure on the ground that probation is not punishment. Implicit in such cases is the conclusion that once probation is recognized as punishment, an impermissible "second punishment is any loss of liberty that goes beyond the judgment of the court in the initial prosecution." Hall v. Bostic, 391 F. Supp. 1297, 1302 (W.D.N.C. 1974) (probation is punishment for double jeopardy purposes), rev'd, 529 F.2d 990 (4th Cir. 1975) (probation is nonpunitive), cert. denied, 425 U.S. 954 (1976).

106. The ban on increased punishment requires the court to impose the total punishment at the outset even though the legislature has statutorily authorized delaying imposition of a prison term or fine until revocation of probation. See I8 U.S.C. $\$$ S $365 \mathrm{I}$, 3653 (1976) (authorizing imposition of prison term or fine at time of revocation). Although the Court's decision in United States v. Difrancesco, 101 S. Ct. 426 (1980), might be interpreted as holding that the legislature may circumvent the ban on increased punishment by statute, that decision should not be extended beyond its particular facts. In DiFrancesco, the Court, in a 5.4 decision, reversed the ruling of the Court of Appeals for the Second Circuit, 604 F.2d 769, 779-87 (1979), and upheld a statute authorizing the government to appeal a special dangerous offender's sentence for an increase in length.

In addition to the reasons provided by the principal dissent, see $101 \mathrm{~S}$. Ct. at $440-45$, other considerations cast doubt on the soundness of the Court's holding. First, the Court's rationale in Difrancesco, that the legislature may, by statute, provide for nonfinal sentences, renders the ban on increased punishment, which is "a constitutional policy of finality for the defendant's benefit," United States v. Jorn, 400 U.S. 470, 479 (1971) (plurality opinion), a mere statutory policy that can be easily circumvented. But "[a] primary purpose ... [of the double jeopardy clause] is . . . to preserve the finality of judgments," Crist v. Bretz, 437 U.S. 28, 33 (1978), and "[i]n a criminal case final judgment means sentence," Pollard v. United States, 352 U.S. 354, 360 n.4 (1957) (quoting Miller v. Aderhold, 288 U.S. 206, 210 (1933)). But cf. Westen, The Three Faces of Double Jeopardy: Reflections on Government Appeals of Criminal Sentences, 78 MICH. L. REv. 1001, 1023-33 (1980) (imposition of multiple punishment permissible if legislature clearly intends it). Second, the Court, in focusing solely on the analogy between barring retrial 
not increase the severity of the probationary conditions ${ }^{107}$ unless new restrictions were required to respond to actions committed by the offender while on probation. ${ }^{108}$ The court must therefore decide, when placing the defendant on probation, which punitive restrictions, if any, should be conditions of probation.

\section{Conclusion}

The double jeopardy clause prohibits multiple punishment for a single offense. In challenging a practice under the multiple-punishment doctrine, the offender must establish that the practice constitutes punishment. Courts have, though, adopted too narrow a definition of punishment, finding a practice punitive only if it is imposed with the intention of punishing the offender. The double jeopardy clause requires a broader definition of punishment, one that focuses on the effect that the practice has upon the offender. By adopting an effects test, courts would bring within the multiple-punishment doctrine several sanctions, such as probation, that have heretofore been considered nonpunitive and would thereby serve the purposes of the double jeopardy clause.

after acquittal and recognizing an implied acquittal of a greater sentence, completely overlooked the importance of the bar on retrial after conviction. See note 17 supra (purpose of bar on retrial after conviction is to preserve finality of initial sentence). Finally, the Court's suggestion that, historically, double jeopardy principles were concerned exclusively with the bar on retrials, see $101 \mathrm{~S}$. Ct. at 435 , not the ban on multiple punishment, is incorrect. To the contrary, concern about multiple punishment, not retrial, was probably responsible for the development of the concept of double jcopardy in the common law. See note 2 supra (discussing historical background of double jeopardy principle).

107. This restriction is premised on the ban against substitute punishment, see note 22 supra, which concerns imposing a more severe type of punishment, not increasing the period of punishment. Although the cases concerning this protection have involved substituting one form of punishment for another, for example, imprisonment for probation, see id., the underlying principle, that the severity of the punishment may not be increased by the court, also applies when the court attempts sua sponte to increase the severity of a particular form of punishment through additional restrictions.

108. See note 27 supra (ban on substitute punishment not violated if more severe form of punishment imposed in response to defendant's actions).

Although both the ban on increasing the length of punishment, see note 22. supra, and the ban on substitute punishment, see id., accord the defendant's sentence finality, they are not of equal force. A probationer's improper conduct may result in revocation of probation and a substitute punishment, imprisonment, even though the same conduct cannot be used to lengthen the period of punishment. In the substitute punishment context, the probationer's interest in finality is outweighed by society's interest in providing the defendant an incentive, the threat of incarceration, to obey his conditions of probation. Indeed, if probation were held not revocable, its use would probably be discontinued, a result that defendants as a class would not desire. On the increased length issue, there is no countervailing societal value to requiring the court to impose the total length of punishment at the outset. Since the probation and the subsequent prison term are served for the same initial criminal conduct, see note 93 supra, the judge can determine after trial the appropriate maximum punishment for the defendant's offense. 